\title{
Studies of a popliteal synovial fistula
}

\author{
R. M. BENNETT,* G. R. V. HUGHES, E. G. L. BYWATERS, AND P. J. L. HOLT \\ Rheumatology Unit, Department of Medicine, Royal Postgraduate Medical School, London, W.12
}

Synovial fistulae occur only rarely as a spontaneous complication of rheumatoid arthritis, usually in relation to the small joints of the hands and feet (Bywaters, 1953; Rosin and Toghill, 1963). We are unaware of synovial fistulae in relation to a knee joint having been previously described either as a spontaneous occurrence or as a complication of surgery. The case recorded here afforded a unique opportunity to study synovial fluid output in terms of diurnal volume and composition, including blood loss.

\section{Case report}

A 51-year-old woman previously in good health, first presented at another hospital with pain in the left forefoot. Over the next 2 years she developed pain and swelling in the left wrist, the right knee, and the small joints of both hands. Rheumatoid arthritis was diagnosed and she was treated with phenylbutazone, indomethacin suppositories, and gold injections.

A tense swelling developed behind the right knee 6 months later. She was referred to a general surgeon and an initial diagnosis of fibrosarcoma was made. However, at operation, a synovial popliteal cyst was found and removed. After this, synovial fluid began to leak from the lower end of the wound and during the next 2 months a fistulous track developed (Fig. 1).

At this stage the patient was referred to the Rheumatology Unit at Hammersmith Hospital.

\section{Examination}

She was a pale woman with rheumatoid deformities. Nodules and vasculitic lesions were absent. There was swelling of both knees with a small effusion on the left side. Synovial fluid leaked from a fistula into the lower central part of the right popliteal fossa. The lymph nodes in the groin, axillae, and neck were moderately and equally enlarged and the spleen was palpable two fingers breadths below the costal margin.

\section{Laboratory investigations}

$\mathrm{Hb} 7.2$ g./100 ml. Red blood cells $3.34 \times 10^{6} / \mathrm{cu} . \mathrm{mm}$. Reticulocytes 2 per cent., White blood cells $5,800 / \mathrm{cu} . \mathrm{mm}$. Mean corpuscular haemoglobin concentration 31 per cent. Platelets $660 \times 10^{3} / \mathrm{cu} . \mathrm{mm}$. Erythrocyte sedimentation rate $76 \mathrm{~mm}$./hr (Westergren).

Blood film showed anisocytosis, poikilocytosis, and polychromasia.

Accepted for publication April 21, 1972

* Present address: Dr. R. M. Bennett, Department of Medicine, University of Chicago, 950 E 59th Street, Chicago, Illinois 60637, U.S.A.

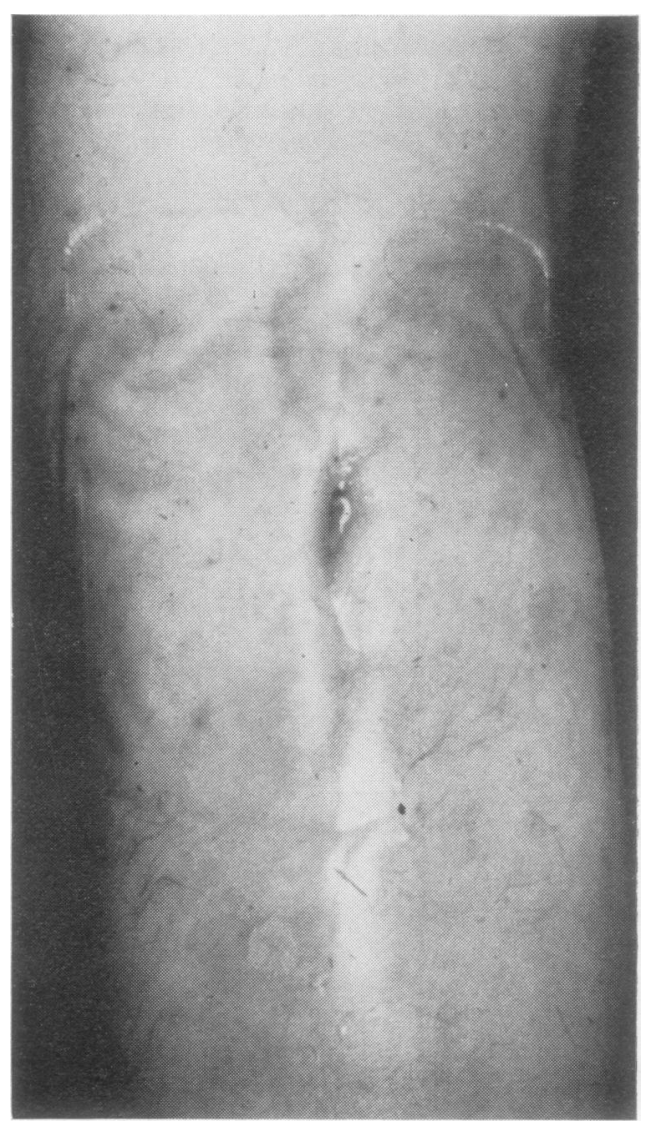

FIG. 1 Opening of fistula into popliteal fossa

Serum iron $10 \mu \mathrm{g} . / 100 \mathrm{ml}$. Total iron-binding capacity $229 \mu \mathrm{g} . / 100 \mathrm{ml}$.

Bone marrow-active normoblastic erythropoiesis with normal iron stores, plasmocytosis compatible with rheumatoid arthritis, and poor incorporation of iron into normoblasts.

Coombs's test negative. Urea $30 \mathrm{mg} . / 100 \mathrm{ml}$. Total protein $3 \cdot 1 \mathrm{~g} . / 100 \mathrm{ml}$. Albumin $1 \cdot 4 \mathrm{~g} . / 100 \mathrm{ml}$.

Faecal occult blood repeatedly negative.

\section{Treatment}

After an initial trial of rest in bed, it was decided that the only logical way of closing the fistula was to remove the 
source of the leaking fluid. A combined synovectomy and closure of the fistula was therefore planned. Before this operation was performed it was possible to study the patient in greater detail.

\section{Results}

SYNOVIAL FLUID VOLUMES

By applying an ileostomy bag over the fistula it was possible to obtain accurately timed collections of synovial fluid. The bag was changed at $06.00,12.00$, and 18.00 hours. The total volume of fluid was measured and kept in sterile containers at $4^{\circ} \mathrm{C}$. Table I shows the daily and diurnal fluctuation in synovial fluid output.

Table I Diurnal synovial fluid collected ( $\mathrm{ml}$.)

\begin{tabular}{|c|c|c|c|c|}
\hline \multirow[t]{2}{*}{ Day } & \multirow{2}{*}{$\frac{\text { Night }}{1800-0600}$} & \multicolumn{2}{|l|}{ Day } & \multirow[t]{2}{*}{ Total } \\
\hline & & $0600-1200$ & $1200-1800$ & \\
\hline 1 & 30 & 50 & 27 & 107 \\
\hline 2 & 0 & 36 & 4 & 40 \\
\hline 3 & 0 & 36 & 0 & 36 \\
\hline 4 & 0 & 77 & 0 & 77 \\
\hline 5 & 4 & 30 & 15 & 49 \\
\hline 6 & 5 & 55 & 0 & 60 \\
\hline 7 & 20 & 65 & 90 & 175 \\
\hline 8 & 0 & 8 & 3 & 11 \\
\hline 9 & 40 & 120 & 38 & 198 \\
\hline 10 & 8 & 70 & 35 & 113 \\
\hline 11 & 10 & 73 & 35 & 118 \\
\hline 12 & 11 & 25 & 0 & 36 \\
\hline
\end{tabular}

Three features of particular interest became apparent:

(1) The specimen of synovial fluid produced during the night was invariably clear but as soon as the patient started walking around it became uniformly blood-stained (Fig. 2).

(2) The nocturnal resting volumes (18.00 to $6.00 \mathrm{hrs)}$ were always less than the daytime collections.

(3) On Day 8, when only $11 \mathrm{ml}$. of synovial fluid were collected, the knee became very painful and swollen, but this was dramatically alleviated the next day when $198 \mathrm{ml}$. of fluid were collected.

\section{BIOCHEMICAL COMPOSITION}

A comparison was made of various biochemical values in synovial fluid and serum (Table II). Values for samples taken on different days are shown to give some idea of the variability encountered. As is usually found, the smaller molecular weight substances had similar values in serum and synovial fluid, while the larger molecular weight substances were found in a reduced concentration in the synovial fluid.

\section{RADIOGRAPHS}

An arthrogram was performed by putting $20 \mathrm{ml}$. 45 per cent. Hypaque into the suprapatellar bursa on

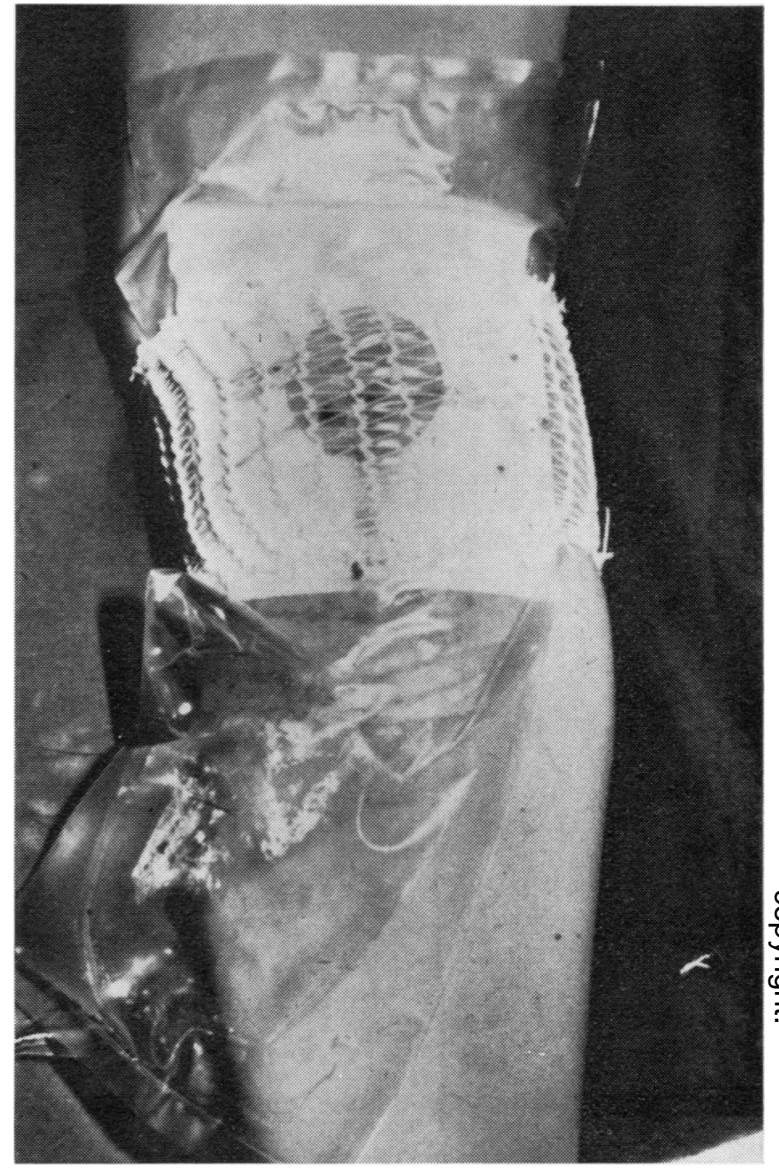

FIG. 2 Blood-stained synovial fuid in ileostomy bag

Table II Simultaneous biochemical values for serum and synovial fluid

\begin{tabular}{|c|c|c|}
\hline Values estimated & $\begin{array}{l}\text { Synovial fluid } \\
\text { per } 100 \mathrm{ml} .\end{array}$ & $\begin{array}{l}\text { Serum } \\
\text { per } 100 \mathrm{ml} .\end{array}$ \\
\hline $\begin{array}{l}\text { Total protein (g.) } \\
\text { Albumin (g.) } \\
\text { IgG (mg). } \\
\text { IgA (mg.) } \\
\text { IgM (mg.) } \\
\text { Free iron (ug.) } \\
\text { Total iron-binding capacity } \\
\text { (ug.) } \\
\text { Transferrin (mg.) }\end{array}$ & $\begin{array}{l}3 \cdot 0,3 \cdot 5,3 \cdot 2 \\
1 \cdot 2,1 \cdot 4,1 \cdot 9 \\
620 \\
250 \\
41 \\
22,26,24 \\
166,145 \\
86 .\end{array}$ & $\begin{array}{l}3 \cdot 6,3 \cdot 7,3 \cdot 2 \\
1 \cdot 4,1 \cdot 9,1 \cdot 6 \\
1,050 \\
365 \\
68 \\
10,20,23 \\
229,270 \\
92\end{array}$ \\
\hline
\end{tabular}

the right side. After the patient had walked for 5 minutes the Hypaque was seen outlining the joint and also reaching the skin surface in the popliteal fossa. Later Hypaque under pressure was instilled into the fistula: only the fistulous track was visualized, no contrast material passed forward into the knee joint. 
BACTERIOLOGY

The fluid from the fistula repeatedly grew coagulasepositive Staphylococcus aureus, but the patient remained apyrexial and the joint showed no signs of infection. Synovial fluid taken directly from the right knee by needle puncture was sterile. The growth of various laboratory strains of Staphylococcus aureus showed inhibition when incubated with undiluted fluid, but the strain isolated from the synovial fistula was not inhibited.

\section{HISTOLOGY}

The popliteal cyst from the first operation was lined with granulation tissue and dense fibrous tissue attached to muscle. In one area there were invaginations in the fibrous wall filled with granulation tissue and large foamy macrophages. The material within the cavity consisted of polymorphonuclear leucocytes and fibrin, the appearance being that of an infected Baker's cyst. The second synovectomy specimen showed a proliferation of synovial cells and a chronic inflammatory infiltrate with both plasma cells and lymphocytes characteristic of rheumatoid arthritis; no organisms were found.

\section{ISOTOPIC STUDIES}

Further investigation of the anaemia was undertaken using $\mathrm{Fe}^{59}$-labelled transferrin to study iron kinetics and $\mathrm{Cr}^{51}$-labelled red blood cells to follow red blood cell survival (Dacie and Lewis, 1963). Surface counting for $\mathrm{Fe}^{59}$ and $\mathrm{Cr}^{51}$ was performed over the sacrum, liver, spleen, heart, and both knees (Figs 3 and 4). The minimal count for $\mathrm{Cr}^{51}$ was at least 1,000 above background (giving a 6.5 per cent. counting error) and for $\mathrm{Fe}^{59}$ was at least 2,000 (giving a 4.5 per cent. counting error). The surface counting results are expressed as a percentage of the count at each site at about 5 minutes after injection. The results are shown in Table III (with normal values calculated for a corresponding height and weight). It can be seen that the anaemia is partly dilutional because of increased plasma volume. The red cell life span was at the lower limit of normal and there was sequestration of red blood cells in the liver and spleen. The plasma clearance of transferrin-bound iron was very rapid, going mainly to the bone marrow (see trace of sacrum, Fig. 3) and there was a 100 per cent incorporation into red blood cells by 7 days. The $\mathrm{Fe}^{59}$ counts over the knees showed a 100 per cent. increase in the first 24 hours followed by a decline over the next 15 days. The $\mathrm{Cr}^{51}$ counts over each knee showed an erratic pattern.

FOLLOW-UP RESULTS

6 months after closure of the fistula the serum albumin had risen to $3.6 \mathrm{~g}$./ $/ \mathrm{ml}$., but serum values for haemoglobin, platelets, and serum iron all remained unchanged compared to the preoperative levels.

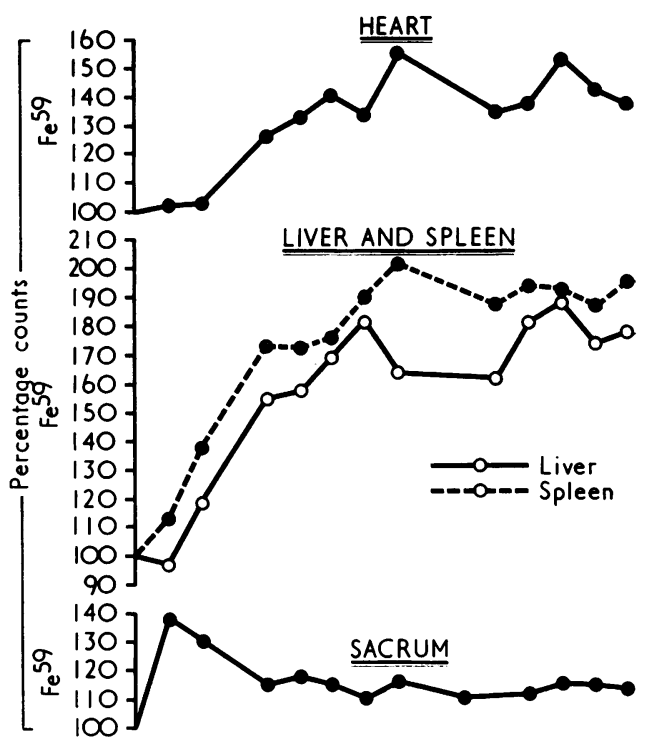

FIG. 3 Surface counting results in heart, liver, spleen, and sacrum

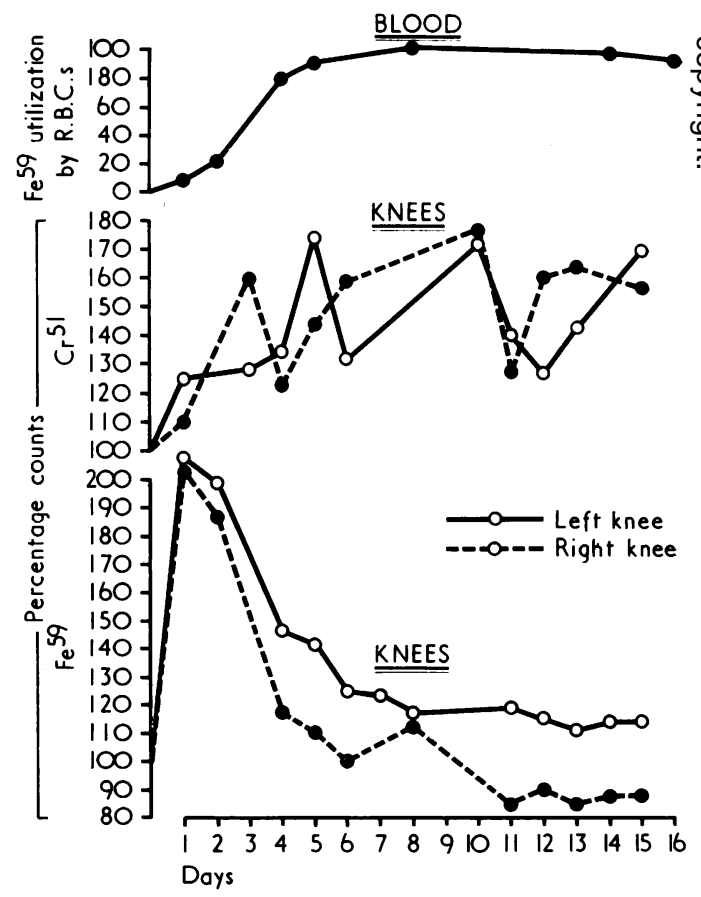

FIG. 4 Iron incorporation by red blood cells and surface counting over right and left knees

\section{Discussion}

NATURE OF FISTULA

The development of a fistula after removal of a 
Table III Ferrokinetic and chromium survival studies

\begin{tabular}{|c|c|c|}
\hline Values estimated & Patient's & Normal \\
\hline Total blood volume (ml.) & 6,569 & $3,000-4,400$ \\
\hline Plasma volume (ml.) & 5,074 & $2,000-2,750$ \\
\hline $\begin{array}{l}\text { Red cell volume (ml.) } \\
\mathrm{T} \frac{1}{2} \mathrm{Cr}^{51} \text { (days) }\end{array}$ & $\begin{array}{r}1,495 \\
25\end{array}$ & $\begin{array}{c}1,210-1,595 \\
25-32\end{array}$ \\
\hline $\begin{array}{l}\mathrm{T}_{2}^{\frac{1}{2}} \mathrm{Fe}^{59} \text { plasma clearance } \\
\text { (min.) }\end{array}$ & 29 & $60-140$ \\
\hline $\begin{array}{l}\text { Plasma iron turnover } \\
\text { (ug./100 ml./day) }\end{array}$ & $0 \cdot 23$ & $0.38-0.77$ \\
\hline $\begin{array}{l}\text { Synovial fluid blood loss } \\
(\mathrm{ml} . / 100 \mathrm{ml} .)\end{array}$ & 3 & - \\
\hline Iron utilization by $\mathbf{R B C s}$ & $\begin{array}{l}100 \text { per cent./ } \\
5 \text { days }\end{array}$ & $\begin{array}{l}70 \text { to } 80 \text { per cent./ } \\
10 \text { to } 14 \text { days }\end{array}$ \\
\hline
\end{tabular}

Baker's cyst without an accompanying synovectomy, might be expected to occur since the source of exudate is still present and the flow of fluid is from the joint cavity into the cyst. Three pieces of evidence support the concept of this unidirectional flow of synovial fluid. Hypaque injected intra-articularly readily appeared in the fistula but, when injected under pressure into the fistula, did not gain access to the joint cavity. A similar unidirectional flow was found in several patients, with popliteal cysts, on arthrography by Hall and Scott (1966). Pressure recordings in Baker's cysts (Jayson and Dixon, 1970a) have shown increased pressure in the cyst compared with the joint cavity and pressure fluctuation in the cyst on tensing the quadriceps but no corresponding increase in the intra-articular pressure on pressing the cyst. Indeed, the pressure in the knee joint with quadriceps contraction may rise, in patients with effusion, well over arterial systolic pressure (Caughey and Bywaters, 1963). Finally, post mortem studies show that the communication between the knee joint and popliteal cyst is usually between the heads of the gastrocnemius and has a valve-like structure, allowing fluid to flow in only one direction (Taylor, 1971).

SYNOVIAL FLUID VOLUMES, COMPOSITION AND BLOOD LOSS

The rate of synovial fluid production in health and disease is not known. The average daily output derived from our figures over 12 days is 79 ml., with diurnal fluctuations showing an increased daytime output during periods of exertion. Increased synovial fluid volumes are associated with increased intra-articular pressure on exertion especially in disease (Jayson and Dixon, 1970b). However, in the presence of a fistula, intra-articular pressures will be relatively low, thus decreasing one important aspect of interstitial fluid exchange. Our figures cannot therefore be compared with the synovial fluid production and composition in an inflamed joint without a fistula.

The finding that the synovial fluid was bloodstained after exertion is not unexpected when one considers the hypertrophy and increased vascularity of rheumatoid synovium. Although such a phenomenon has often been postulated, its actual occurrence has not, to the best of our knowledge, been previously demonstrated. The fluctuating $\mathrm{Cr}^{51}$ surface counting trace indicates that intermittent bleeding was also occurring into the left knee, i.e. in the absence of a fistula. Synovial fluid from inflamed rheumatoid joints seldom contains grossly visible blood (assuming an atraumatic puncture), probably through the extremely effective phagocytosis of synovial membrane, but there are always some red blood cells microscopically.

THE ANAEMIA

Of major importance in this patient's anaemia is a greatly increased plasma volume in the presence of a normal red cell mass (Table III) leading to a dilutional anaemia. This cause of anaemia is well documented in rheumatoid arthritis; it is thought to be the result of the increased plasma volume 'trapped' within an enlarged spleen (Prankerd, 1963) and probably plays a major role in the anaemia of Felty's syndrome (Blendis, Ansell, Lloyd-Jones, Hamilton, and Williams, 1970). In addition, the surface counting results indicate sequestration of red cells within the spleen with subsequent breakdown and storage of their iron.

It is interesting that the patient had a persistently increased platelet count which is always suggestive of chronic bleeding. Her faecal occult blood tests were always negative but there was persistent escape of blood and iron from the fistula. We estimate that, during the 7 months before closure of the fistula, $450 \mathrm{ml}$. of blood were lost. If a similar amount of blood was lost from the circulation into the left knee (as suggested by the $\mathrm{Cr}^{51}$ counting) the patient probably lost nearly a litre of blood over the course of 7 months, into her knees alone. An increased platelet count in the absence of obvious bleeding is fairly common in rheumatoid patients (personal observation) and we suggest this could result partly from chronic intra-articular bleeding, producing an occult blood loss, in the true sense of the word, as the red cells are rapidly phagocytosed and the iron sequestrated into the synovial membrane.

It has been proposed (Muirden, 1970) that deposition of iron in the synovial membrane and its subsequent nonavailability for erythropoiesis is an important contributory factor in the anaemia of rheumatoid arthritis. The surface counting results in this patient suggest that synovial iron deposition is only a reflection on a small scale of a generally increased sequestration of iron from effete red blood cells by a hyperactive reticuloendothelial system.

The rise in the serum albumin 6 months after closure of the fistula $(1.4$ to $3.6 \mathrm{~g}$./ml.) suggests that the initial low value was partly dependent upon loss 
through the fistula. We estimate that before the fistula was closed she had lost approximately $220 \mathrm{~g}$. albumin by this route. The failure of haemoglobin, platelets, and serum iron to change significantly indicates either that the loss of blood from the fistula was insignificant or that the status quo was being maintained by continuing intra-articular bleeding and sequestration.

\section{Summary}

A patient with rheumatoid arthritis developed a synovial fistula after the removal of a Baker's cyst. Diurnal variations in synovial fluid output and content were recorded and the resulting loss of blood and other substances is discussed in relation to the patient's blood picture and serum biochemical values.

We thank Mr. W. H. Stephenson (Orthopaedics), Dr. Slavin (Biochemistry Department), and members of the Bacteriology and Haematology Department for their assistance. This work was supported in part by the Arthritis and Rheumatism Council.

\section{References}

Blendis, L. M., Ansell, I. D., Lloyd-Jones, K., Hamilton, E., AND Williams, R. (1970) Brit. med.J., 1, 131 (Liver in Felty's syndrome)

BYwATERS, E. G. L. (1935) Ann. rheum. Dis., 12, 114 (Fistulous rheumatism, a manifestation of rheumatoid arthritis)

CAugheY, D. E., AND BYwaters, E. G. L. (1963) Ibid. 22, 106 (Joint fluid pressure in chronic knee effusions)

DACIE, J. V., AND LeWIS, S. M. (1963) 'Practical Haematology', 3rd ed., chap. 13. Churchill, London

Hall, A. P., AND Scott, J. T. (1966) Ann. rheum. Dis., 25, 32 (Synovial cysts and rupture of the knee joint in rheumatoid arthritis. An arthrographic study)

JAYson, M. I. V., AND Dixon, A. ST. J. (1970a) Clin. Sci. 38, 24 (Valvular mechanisms in the formation of synovial cysts) (1970b) Ann. rheum. Dis., 29, 401 (Intra-articular pressure in rheumatoid arthritis of the knee. III. Pressure changes during joint use)

MuIRDEN, K. D. (1970) Aust. Ann. Med., 19, 97 (The anaemia of rheumatoid arthritis: the significance of iron deposits in the synovial membrane)

Prankerd, T. A. J. (1963) Brit. med. J., 2, 517 (The spleen and anaemia)

Rosin, A. J., AND Toghill, P. J. (1963) Postgrad. med. J., 39, 96 (Fistulous rheumatism. An unusual complication of rheumatoid arthritis)

TAYLOR, A. R. (1971) VII European Rheumatology Congress, Abstract 3, p. 15 (The formation of popliteal cysts) 